\title{
RESIKO MEDIS DAN KELALAIAN MEDIS DALAM ASPEK PERTANGGUNGJAWABAN PIDANA
}

\author{
Oleh \\ Wahyu Rizki Kartika Ilahi \\ Mahasiswa Pascasarjana Magister Hukum Universitas Airlangga
}

\begin{abstract}
Healthy is very important for every people, keep healthy is very important, if some people ill and must opname when the doctor must get to make medic for some people, but the end of get medic is unsatisfactory result.in the term of unsatisfactory result from get medic, make medical loss for patient and patient's family, in medical loss result make many issues for doctor. but must know in the fact, not every unsatisfactory result get responsibility.this thesis make a normative yuridis metode with statue approach and conceptualapproach metode. in this thesis discuss about responsibility doctor for medical risks and medical risks which can be account for by doctor.

Key words :Medical Risks, Negligence, Accountability Doctor
\end{abstract}

\section{A. PENDAHULUAN}

A state of complete physical, mental, and social, well being and not merely the absence of desease or infirmity(Hermien Hadiati Koeswadji, 1992: Hlm 17). Pernyataan tersebut jika di artikan secara bebas bahwa sebuah keadaan fisik, mental, dan sosial, kesejahteraan, bukan hanya mengenai adanya penyakit atau kelemahan.

Kesehatan adalah keadaan sehat, baik secara fisik, mental, spiritual maupun sosial yang memungkinkan setiap orang untuk hidup produktif secara sosial dan ekonomis.Kesehatan merupakan harta yang paling berharga di dunia ini maka dari itu upaya peningkatan mutu kesehatan semakin diupayakan. Pengupayaan peningkatan kesehatan oleh negara ini tidak lain bertujuan untuk meningkatkan kualitas hidup manusia. Jika kualitas hidup manusia meningkat maka kesejahteraan pun akan di dapat.

Dalam Undang-Undang Dasar Negara Republik Indonesia tahun 1945 Pasal 28A tercantum "setiap orang berhak untuk hidup serta berhak mempertahankan hidup dan kehidupannya". Berhak mempertahankan hidup dan kehidupannya berarti setiap orang berhak untuk mendapatkan kesempatan yang sama untuk mempertahankan hidup dan kehidupannya. Mempertahankan hidup juga termasuk berhak untuk mendapatkan 
pelayanan kesehatan yang baik. Oleh sebab itu peningkatan mutu pelayanan kesehatan semakin digencarkan. Kebijakan-kebijakan yang diambil oleh pemerintah haruslah mencakup semua lini dan lapisan masyarakat karena kesehatan juga menjadi salah satu hak asasi manusia yang dilindungi dan dijamin oleh negara.

Dalam Pasal 28H Undang-Undang Dasar Negara Republik Indonesia tahun 1945 ditekankan bahwa "Setiap orang berhak hidup sejahtera lahir dan batin, bertempat tinggal, dan mendapatkan lingkungan hidup yang baik dan sehat serta berhak memperoleh pelayanan kesehatan".

Pemerintah dalam upaya peningkatan mutu kesehatan haruslah dapat membentuk produk-produk hukum yang mendukung peningkatan mutu para dokter dan petugas medisserta pengembangan teknologi-teknologi medis. Produk-produk hukum tersebut juga harus mengatur bagaimana pelayanan kesehatan yang lebih baik dan melindungi para petugas medis serta pasien agar dapat melaksanakan kewajiban dan menerima haknya dengan seoptimal mungkin.

Hubungan dokter dan pasien sudah berjalan sejak masa Hipocrates dan terus berkembang hingga sekarang. Perkembangan terus bergulir hingga terjadi pergantian teknologi,perkembangan ilmiah serta sosial, perkembangan ini sendiri mengakibatkan terjadinya perubahan cara pelayanan kesehatan serta tindakan-tindakan medis yang dilakukan oleh dokter. Hal ini merupakan tantangan bagi konsep-konsep dan kewajibankewajiban moral para tenaga medis dan masyarakat yang secara nyata berlaku saat ada pasien yang sakit atau mengalami resiko medis atas dilakukannya tindakan medis oleh dokter.

Suprapti Samil (2007,hlm.60-61) mengatakan bahwa hubungan antar manusia (baca hubungan antara dokter dengan pasien), hubungan antara dokter dengan pasien telah diatur dengan nilai- nilai kesopanan (mores),yang berarti adat istiadat, kelakuan, tabiat, watak, akhlak dan kesusilaan (ethica). Dimana selanjutnya dikatakan oleh Suprapti Samil di dalam KODEKI 1980 bahwa istilah etik terbentuk dari dua perkataan yanitu "mores of a community" dan "ethos of the people". 
Konsep tersebut mengandung makna bahwa dalam hubungan antara dokter dengan pasien harus didasari oleh nilai - nilai dan moral serta itikad yang baik demi terselenggaranya pelayanan kesehatan yang baik dan berkesinambungan.Hubungan dokter - pasien yang dahulu bersifat paternalistik dan kepercayaan (trust, vertrouwen, fiduciary relationship) kini sudah mengalami erosi. Kepercayaan mulai goyah. Jika dahulu pasien percaya saja apa yang dilakukan oleh profesi dokter,kini masyarakat mulai mempertanyakan jika pengobatannya tidak berhasil,berakibat cacat berat, atau bahkan sampai meninggal(Guwandi: 2009,hal 1-2).

Dalam hubungan antara dokter dan pasien dikenal perjanjian terapeutik, perjanjian terapeutik atau transaksi terapeutik adalah perjanjian antara dokter dengan pasien yang memberikan kewenangan kepada dokter untuk melakukan kegiatan memberikan pelayanan kesehatan kepada pasien berdasarkan keahlian dan keterampilan yang dimiliki oleh dokter tersebut (AnnyIsfandyarie: 2006,hlm 57).

Komalawati terhadap perjanjian teraupetik berlaku hukum perikatan yang diatur dalam buku III KUHPerdata, sebagaimana disebutkan di dalam Pasal 1320 KUHPerdata yang berbunyi :

“ Semua Perjanjian, baik yang mempunyai suatu nama khusus,maupun yang tidak dikenal dengan suatu nama tertentu, tunduk pada peraturan umum, yang termuat dalam Bab ini dan Bab yang lalu”.

Namun perjanjian teraupetik berbeda dengan perjanjian pada umumnya karena memiliki objek perjanjian ynang berbeda dengan perjanjian pada umumnya. Perjanjian teraupetik atau trandaksi teraupetik termasuk dalam inspanningverbintenis atau perjanjian upaya, karena dokter tidak mungkin menjanjikan kesembuhan kepadapasien, yang dilakukan dokter adalah melakukan pelayanan kesehatan sebagai upaya untuk menyembuhkan pasien

Perjanjian teraupetik mengikat layaknya undang - undang bagi dokter maupun pasien. Seperti halnya yang diatur di dalam Pasal 1338 KUHPerdata yang berbunyi :

“Semua Perjanjian yang dibuat secara sah berlaku sebagai undang - undang bagi mereka yang membuatnya". 
Profesi dokter juga memiliki etik kedokteran. Etik kedokteran adalah norma dan asas yang berlaku bagi para dokter sebagai landasan dalam menjalankan profesinya.

Dalam praktiknya apa yang dimaksud dengan etik kedokteran ini,mempunyai dua sisi dimana satu sama lain saling terkait dan saling pengaruh - mempengaruhi. Kedua sisi tersebut adalah: Pertama, etik jabatan atau yang dikenal dengan istilah medical ethics, yaitu menyangkut masalah yang berhubungan dengan sikap para dokter terhadap sejawatnya,sikap dokter tehadap para pembantunya dan sikap para dokter terhadap masyarakat dan pemerintah. Kedua,etik asuhan atau yang dikenal dengan sebutan ethics of the medical care,yaitu, merupakan etik kedokteran dalam kehidupan sehari - hari mengenai sikap dan tindakan seorang dokter terhadap penderita yang menjadi tanggung jawabnya(Bahder Johan Nasution: 2013, hlm 9).

Dewasa ini sering muncul kasus - kasus dalam pelayanan kesehatan yang mengakibatkan kinerja dokter diragukan serta mengancam keberlangsungan karir seorang dokter. Kasus yang paling baru adalah kasus operasi sesar yang mengakibatkan kematian pasiennya dilakukan olehdokter Dewa Ayu Sasiary Prawan. Pada kasus dokter Dewa Ayu Sasiary Prawan, majelis hakim pengadilan negeri dan pengadilan tinggi memutus bebas namun majelis hakim tingkat kasasi memutus bersalah dokter Ayu. Pada saat peninjauan kembali, dokter Ayu diputus bebas oleh hakim. Kasus-kasus tersebut diajukan ke pengadilan karena terdapat ketidakpuasan atas hasil dari pelayanan kesehatan yang dilakukan oleh dokter maupun adanya indikasi kesalahan prosedur atau kode etik kedokteran.

Pengertian resiko medis tidak dirumuskan secara eksplisit dalam peraturan perundang-undangan yang ada. Namun secara tersirat resiko medis disebutkan di dalam beberapa pernyataan yang ada mengenai resiko terhadap tindakan medis(Anny Isfandyarie: 2005,hlm38). Resiko atas dijalankannya pelayanan medis sangat tidak dapat diprediksi karena petugas medis hanya bisa berupaya semaksimal mungkin untuk melakukan penanganan medis. Sekalipun dapat diduga apa saja resiko medis yang dapat terjadi,tetap saja tidak dapat dipastikan resiko mana yang akan diperoleh pasien atas penanganan petugas medis tersebut. Tidak jarang resiko medis yang terjadi berujung pada 
kematian sehingga petugas medis dalam hal ini dokter diduga melakukan kesalahan atau kelalaian yang mengakibatkan kematian seseorang.

Berdasarkan pada pemaparan dalam latar belakang dan uraian masalah diatas, maka ruang lingkup penelitian dapat diambil rumusan permasalahan antara lain yaituApa kategori tindakan medis yang termasuk resiko medis dan kelalaian medis dan Bagaimana pertanggungjawaban pidana terhadap resiko medis yang berujung kelalaian medis bagi dokter

\section{B. METODE PENELITIAN}

Tipe penelitian yang digunakan ialah penelitian secara normative, yaitu metode pendekatan melalui pengkajian terhadap asas - asas hukum dan sistematika hukum yang ada di dalam peraturan perundang-undangan yang berlaku. Sehingga penelitian secara normative ini dapat fokus pada inventarisasi hukum positif, dan penemuan hukum dalam perkara inconcreto dalam penanganan kasus.

Dalam penyusunan dan penulisan skripsi ini penulis menggunakan pendekatan masalah dengan beberapa metode yang ada yaitu ; metode pendekatan undang-undang (statute approach), pendekatan kasus (case approach), dan pendekatan konseptual (conceptual approach).

Peter Mahmud Marzuki (2013:33) menguraikan pendekatan pendekatan yang digunakan digunakan dalam penelitian diatas sebagai berikut :

Pendekatan undang-undang (statute approach) dilakukan dengan menelaah semua peraturan perundang-undangan dan regulasi yang bersangkut paut dengan permasalahan yang sedang dibahas.

Pendekatan konseptual (conceptual approach) adalah pendekatan yang dilakukan dengan menggunakan pijakan pandangan-pandangan dan doktrin doktrin yang berkembang dalam ilmu hukum yang terkait dengan kelalailan medis.

\section{PEMBAHASAN}




\section{KONSEP KELALAIAN MEDIS DAN PEMBUKTIANNYA}

Kelalaian dalam hukum pidana disebut juga dengan kealpaan. Langemeyer "Kealpaan adalah suatu struktur yang sangat gecompliceerd. Dia mengandung dalam satu pihak kekeliruan dalam perbuatan lahir dan menunjuk kepada adanya keadaan batin yang tertentu, dan di lain pihak keadaan batinnya itu sendiri"(Moeljatno:1993,hlm200). Van Hammel mengatakan bahwa kealpaan itu mengandung dua syarat yaitu :

1. Tidak mengadakan penduga - duga sebagaimana diharuskan oleh hukum.

2. Tidak mengadakan penghati - hati sebagaimana diharuskan oleh hukum.

Konsep kelalaian dalam Kitab Undang - Undang Hukum Pidana (KUHP) dijelaskan dalam Pasal 359 dan Pasal 360 KUHP :

Pasal 359 KUHP

"Barangsiapa karena kealpaannya menyebabkan matinya orang lain diancam pidana penjara paling lama lima tahun atau kurungan paling lama satu tahun".

Pasal 360 ayat (1) KUHP

"Barangsiapa karena kelapaannya menyebabkan orang lain mendapat luka - luka berat, diancam pidana penjara paling lama lima tahun atau kurungan paling lama satu tahun”.

Pasal 360 ayat (2) KUHP

“Barangsiapa karena kealpaannya menyebabkan orang lain luka - luka sedemikian rupa sehingga timbu penyakit atau halangan menjalankan pekerjaan jabatan atau pencarian selama waktu tertentu, diancam dengan pidana penjara paling lama sembilan bulan atau kurungan paling lama enam bulan atau denda paling tinggi tiga ratus rupiah".

Kelalaian medis atau dalam bahasa sehari - hari dikenal dengan istilah malpraktek merupakan salah satu kejadian atau fenomena yang akhir - akhir ini muncul dan menjadi sorotan khalayak. Hal ini dikarenakan beberapa pasien mengalami resiko medis berupa kematian ataupun cacat dan mengakibatkan banyaknya gugatan yang dilayangkan pasien terhadap dokter.

Kelalaian dalam hukum medis sering disebut dengan Negligence. Negligence adalah hal yang manusiawi yang sering dialami oleh manusia karena manusia tidaklah sempurna. Menurut Guwandi (2004:29) Seseorang dikatakan lalai apabila ia bertindak acuh atau tidak 
pedulian.Tidak memperhatikan kepentingan orang lain sebagaimana lazimnya di dalam tata-pergaulan hidup masyarakat.

Pengertian kelalaian medis sendiri menurut Hermien Hadiati Koeswadji secara harfiah berarti bad practice atau praktek buruk yang berkaitan dengan praktek penerapan ilmu dan teknologi medik dalam menjalankan profesi medik yang mengandung ciri - ciri khusus. Karena malpraktek berkaitan dengan "how to practice the medical science and technology", yang sangat erat hubungannya dengan sarana kesehatan atau tempat melakukan praktek dan orang yang melaksanakan praktek,maka pendapat Hermien lebih cenderung menggunakan istilah “maltreatment (Syahrul Machmud: 2008, hlm13).

Black Law Dictionary sebagaimana dikutip oleh HM.Soedjatmiko, merumuskan malpraktek sebagai :

"any profesional misconduct, unreasonable lack of skill or fidelity in professional or judiary duties, evil practice, or illegal or immoral conduct ........."

(perbuatan jahat seseorang ahli, kekurangan dalam keterampilan yang di bawah standar, atau tidak cermatnya seorang ahli dalam menjalankan kewajibannya secara hukum, praktek yang jelek atau illegal atau perbuatan yang tidak bermoral)

Anny Isfandyarie, menyimpulkan sebagai kesalahan dokter karena tidak mempergunakan ilmu pengetahuan dan tingkat keterampilan sesuai dengan standar profesinya yang akhirnya mengakibatkan pasien terluka atau cacat badan bahkan meninggal dunia.

R.Hariadi, malpraktek adalah praktek yang buruk: melakukan yang seharusnya tidak dilakukan atau tidak melakukan apa yang sebenarnya dilakukan. Istilah malpraktek berlaku untuk semua jenis profesi termasuk dokter, akuntan, pengacara dan sebagainya. Di bidang kedokteran bila seorang dokter melakukan malpraktek disebut malpraktek kedokteran atau malpraktek medik (medical malpractice).

J Guwandi, dengan mengutip beberapa pendapat hakim dalam beberapa kasus yang pernah terjadi atau kamus-kamus mengutarakan pengertian malpraktek sebagai berikut:

a. Kasus Valentin v. Society se Bienfaisance de Los Angeles, California, 1956 dirumuskan : 
Malpraktek adalah kelalaian dari dari seorang dokter atau perawat untuk menerapkan tingkat keterampilan dan pengetahuannya di dalam memberikan pelayanan pengobatan dan perawatan terhadap seorang pasien yang lazimnya diterapkan dalam mengobati dan merawat orang sakit atau terluka di lingkungan wilayah yang sama.

"Malpractice is the neglect of a physician or nurse to apply that degree of skill and learning on treating and nursing a patient which is customary applied in treating and caring for the sick or wounded similarly in the same community".

b. Steadman's Medical Dictionary

Malpraktek adalah salah cara mengobati suatu penyakit atau luka, karena disebabkan sikap - tindak yang acuh, sembarangan atau berdasarakan motivasi kriminal.

"Malpractice is mistreatment of a disease or injury throught ignorance, carelessness of criminal intent".

c. Coughlin's Dictionary of Law

Malpraktek adalah "sikap-tindak profesional yang salah dari seorang yang berprofesi, seperti dokter, ahli hukum, akuntan, dokter gigi, dokter hewan.

Malpraktek bisa diakibatkan karena sikap-tindak yang bersifat tak pedulian, kelalaian. Atau kekurangan keterampilan atau kehati - hatian di dalam pelaksanaan kewajiban profesionalnya; tindakan salah atau praktek yang bersifat tidak etis".

"Professional misconduct on the part of a professional person, such as a physician, engineer, lawyer, accountant, dentist, veterinarian.Malpractice may be the result of ignorance, neglect, or lack of skill or fidelity in the performance of professional duties;intentional wrongdoing or unethical practice".

d. Black's Law Dictionary

Malpraktek adalah setiap sikap-tindak yang salah, kekurangan keterampilan dalam ukuran tingkat yang tidak wajar. Istilah ini umumnya dipergunakan terhadap sikaptindak dari para dokter, pengacara, dan akuntan. Kegagalan untuk memberikan pelayang profesional dan melakukan pada ukuran tingkat keterampilan dan 
kepandaian yang wajar di dalam masyarakatnya oleh teman sejawat rata - rata dari profesi itu, sehingga mengakibatkan luka, kehilangan atau kerugian pada penerima pelayanan tersebut yang cenderung menaruh kepercayaan terhadap mereka itu. Termasuk di dalamnya setiap sikap-tindak profesional yang salah, kekurangan keterampilan yang tidak wajar atau kurang kehati - hatian atau kewajiban hukum, praktek buruk, atau illegal atau sikap immoral.

"Any professional misconduct, unreasonable lack of skill. This term is usually applied to such conduct by doctors, lawyers, and accountants. Failure of one rendering professional services to exercise that degree of skill and learning commonly applied under all the circumstances in the community by the average prudent reputable member of the profession with the result of injury, loss or damage to the recipient of those entitled to rely upon them. It is any professional misconduct, unreasonable lack of skill or fidelity in professional or judiciary duties, evil practice, or illegal or immoral conduct".

e. The Oxford Illustrated Dictionary,2nd ed., 1975

Malpraktek = sikap-tindak yang salah; (hukum) pemberian pelayanan terhadap pasien yang tidak benar oleh profesi medis; tindakan yang illegal untuk memperoleh keuntungan sendiri sewaktu dalam posisi kepercayaan.

"Malpratice = wrongdoing; (law) improper treatment of patient by medical attendant; illegal action for one's own benefit while in position trust'.

Maka dapat ditarik kesimpulan bahwa yang dimaksud dengan malpraktek adalah :

1. Melakukan sesuatu yang seharusnya tidak boleh dilakukan oleh seorang tenaga kesehatan.

2. Tidak melakukan apa yang seharusnya dilakukan atau melalikan kewajiban (negligence)

3. Melanggar suatu ketentuan menurut atau berdasarkan peraturan perundang - undangan.

M Yusuf Hanafiah (1999:87), malpraktek adalah kelalaian seorang dokter untuk mempergunakan tingkat keterampilan dan ilmu pengetahuan yang lazim dipergunakan 
dalam mengobati pasien atau orang yang terluka menurut ukuran di lingkungan yang sama.

Dari beberapa pendapat ahli tersebut dapat ditarik sebuah pernyataan bahwa kelalaian medis merupakan kondisi dimana seorang dokter atau tenaga medis melakukan penyimpangan terhadap kode etik kedokteran,standar profesi dokter dan standar operasional prosedur (SOP) saat melakukan tindakan medis terhadap pasiennya sehingga mengakibatkan kerugian yang diderita pasien akibat dari tindakan medis tersebut.

Tolok ukur sekaligus syarat pembuktian kelalaian medis (Guwandi, Jakarta: 2009 hlm 11) di negara Anglo Saxon adalah konsep “4D” dari Negligence yang terdiri atas :

1. Duty

Harus ada hubungan Dokter - Pasien, sehingga ada kewajiban Dokter untuk mengobati pasien

2. Dereliction of that duty

Terdapat suatu Penyimpangan dari "Duty" pada pihak Dokter karena ternyata ia tidak melakukan kewajibannya menurut standar profesi.

\section{Direct causation}

Sehingga timbul suatu kerugian

4. Damage

Namun harus ada kaitan secara langsung antara tindakan yang dilakukan oleh dokter dan kerugian yang timbul.

\section{KETERKAITAN RESIKO MEDIS DAN KELALAIAN MEDIS}

Pengertian resiko medis tidak dijelaskan secara rinci dan jelas di dalam peraturan perundang - undangan yang ada. Oleh karena itu banyak orang yang menyalahartikan tentang resiko medis sehingga banyak tuntutan terhadap dokter di dalam pengadilan.

Resiko medis secara tersirat disebutkan dalam beberapa pernyataan sebagai berikut :

1. Informed Consent secara tertulis merupakan salah satu cara yang perlu dilakukan 
untuk melindungi dokter dari tuntutan pasien,hal ini dikarenakan dalam informed consent, oasien telah sepakat untuk mendapat perlakuan tindakan medis yang akan dilakukan dokter. Dari kesepakatan ini, pasien tidak akan mengadakan tuntutan apapun ke pengadilan di kemudian hari. Selain itu dalam pernyataan tersebut juga dicantumkan bahwa dokter telah menjelaskan sifat, tujuan serta kemungkinan (resiko) akibat yang timbul dari tindakan medik tersebut kepada pasien atau keluarganya.Dokter yang bersangkutan juga harus menandatangani formulir Persetujuan Tindakan Medik termaksud.

2. Pernyataan IDI (Ikatan Dokter Indonesia) tentang Informed Consent dalam Lampiran SKB IDI No. 319/P/BA/88 butir 33 yang berbunyi: "Setiap tindakan medis yang mengandung resiko cukup besar mengharuskan adanya persetujuan tertulis yang ditandatangani oleh pasien, setelah sebelumnya pasien itu memperoleh informasi yang adekuat tentang perlunya tindakan medis yang bersangkutan serta resiko yang berkaitan dengannya."

3. Dalam peraturan perundang - undangan yang berlaku pun secara eksplisit tercantum, dalam Pasal 2 ayat (3), Pasal 3 ayat (1) dan Pasal 7 ayat (2) Peraturan Menteri Kesehatan Republik Indonesia Nomor: 585/Men.Kes/Per/IX/1989 tentang Persetujuan Tindakan Medis menyebutkan istilah resiko secara eksplisit dan tersirat, antara lain:

1. Pasal 2 ayat (1) : Persetujuan sebagaimana dimaksud ayat (1) diberikan setelah pasien mendapat informasi yang adekuat tentang perlunya tindakan medik yang bersangkutan serta resiko yang dapat ditimbulkannya.

2. Pasal 3 ayat (1) : Setiap tindakan medik yang mengandung resiko tinggi harus dengan persetujuan tertulis yang ditandatangani oleh yang hendak memberikan persetujuan.

3. Pasal 7 ayat (2) : Perluasan operasi yang tidak dapat diduga sebelumnya dapat dilakukan untuk menyelamatkan jiwa pasien.

Dari beberapa pernyataan di atas, dapat diambil pengertian resiko medis, yaitu sebagai berikut: 
a. Bahwa dalam tindakan medis ada kemungkinan (resiko) yang dapat terjadi yang mungkin tidak sesuai dengan harapan pasien. Ketidak mengertian pasien terhadap resiko yang dihadapinya dapat mengakibatkan diajukannya tuntutan ke pengadilan oleh pasien tersebut.

b. Bahwa di dalam tindakan medis ada tindakan yang mengandung resiko tinggi.

c. Bahwa resiko tinggi tersebut berkaitan dengan keselamatan jiwa pasien.

Sehingga dapat dikatakan bahwa resiko medis merupakan hasil yang tidak maksimal dari sebuah tindakan medis yang dilakukan oleh dokter.

Resiko medis dapat terjadi karena resiko dari tindakan medis muncul secara tiba tiba diluar perkiraan dokter serta tidak dapat dihindari oleh dokter dan adapula yang timbul karena tindakan medis tersebut dilarang atau dibatasi oleh undang - undang karena tindakan medis tersebut mengandung resiko yang besar. Resiko dari tindakan medis yang dilakukan dokter berbeda - beda skala besar kecilnya. Dokter diminta untuk melakukan tindakan medis yang sesuai dengan kondisi pasien sekalipun resiko yang bersama tindakan medis tersebut besar.

Di dalam Kode Etik Kedokteran Indonesia dokter yang berkewajiban memberikan pertolongan kepada pasiennya haruslah memenuhi standar profesinya sebagai pedoman yang harus dipergunakan dalam menjalankan profesinya secara baik. Hal ini untuk menghindari kerugian pada orang lain sebagai resiko dari tindakan medis yang dilakukan, yang seringkali justru mengakibatkan pasien menuntut secara hukum. Sejak dulu telah dikenal salah satu prinsip tradisional dari etika kedokteran adalah primum non nocere, artinya yang penting adalah tidak merugikan.

Kelalaian medis sendiri diakibatkan karena kurangnya pengetahuan dokter terhadap penyakit pasien atau kurangnya pengetahuan dokter terhadap keilmuan kedokteran. Kelalaian medis terjadi karena dokter tidak mengikuti standar operasional prosedur, standar profesi, dan menurut kalangan profesi dokter sipandang menyalahi kode etik kedokteran sehingga mengakibatkan pasien mengalami kerugian berupa cacat fisik maupun kematian.

Berikut adalah tabel perbandingan antara resiko medis dengan kelalaian medis : 


\begin{tabular}{|l|l|}
\hline \multicolumn{1}{|c|}{ RESIKO MEDIS } & \multicolumn{1}{c|}{ KELALAIAN MEDIS } \\
\hline 1. Sesuai dengan standar operasional prosedur & 1. tidak sesuai dengan standar operasional prosedur \\
\hline 2. Ada kehati - hatian & 2. Tidak unsur kehati - hatian \\
\hline 3. Tidak ada unsur lalai & 3. Ada unsur lalai \\
\hline 4. Ada upaya pencegahan & 4. Tidak ada upaya pencegahan \\
\hline 5. Ada Contributory Negligence & 5. Tidak ada Contributory Negligence \\
\hline
\end{tabular}

Dari penjelasan diatas dapat dilihat bahwa patokan untuk menentukan sebuah hasil pengobatan yang gagal dikategorikan resiko medis atau kelalaian medis adalah dari standar operasional prosedur, standar profesi dan pendapat kalangan profesi dokter sendiri. Ketiga patokan ini juga dapat dilihat dari putusan pengadilan tentang kasus yang menimpa dokter Ayu dan menjadi pertimbangan majelis hakim untuk membebaskan dokter Ayu beserta tim dokternya.

\section{KASUS DUGAAN KELALAIAN MEDIS}

Penulis mengambil contoh kasus yang dialami oleh seorang dokter bernama dr. Dewa Ayu Sasyari Prawanyang melakukan tindakan medis berupa operasi sesar. Kasus dokter Ayumenjadi perdebatan karena dokter Ayudiputus bebas di tingkat pengadilan negeri namun diputus bersalah oleh pengadilan tingkat kasasi namun setelah mengajukan peninjauan kembali, dokter Ayu diputus bebas oleh majelis hakim.Pasien dokter Ayu bernama SISKA MAKATEY dinyatakan meninggal dunia melalui Surat Keterangan dari Rumah Sakit Umum Prof. Dr. R. D.Kandou Manado No. 61/VER/IKF/FK/K/VI/2010, tanggal 26 April 2010 danditandatangani oleh dr. JOHANNIS F. MALLO, SH. SpF. DFM.

Dalam surat keterangan tersebut tercantum bahwa kematian korban akibat masuknya udara ke dalam bilik kanan jantung yang menghambat darah masuk ke paru-paru sehingga terjadi kegagalan fungsi paru dan selanjutnya mengakibatkan kegagalan fungsi jantung. Masuknya udara ini dinilai oleh majelis hakim pengadilan tingkat kasasi menjadi kesalahan dokter dalam memberikan pelayanan medis kepada pasien.

Dalam kasus ini juga disinyalir adanya pemalsuan tanda tangan korban yang dilakukan oleh tim dokter yang menangani korban. Namun dilihat dari kausalitasnya, pemalsuan tanda tangan tersebut bukanlah menjadi penyebab utama matinya korban. Maladministrasi tersebut hanya sebagai tudingan belaka bagi keluarga korban untuk mempermasalahkan kematian korban ke persidangan. Seperti kita lihat bahwa keadaan 
darurat yang dimaksud dalam darurat medis hanyalah kalangan dokter yang mengerti. Maladministrasi yang terjadi hanyalah dipergunakan untuk memenuhi syarat administrasi demi menyelamatkan jiwa pasien karena ketika tim dokter memilih melakukan operasi sesar, kondisi pasien sedang lemah. Kondisi pasien tersebut juga dicantumkan dalam putusan kasasi yang sebagai berikut isinya :

"Berdasarkan keterangan dari saksi dr. HERMANUS JAKOBUS LALENOH, Sp.An. bahwa jawaban konsul terhadap surat konsul yang dikirim oleh bagiankebidanan kepada bagian anestesi tersebut yang menyatakan : pada prinsipnya kami setuju untuk dilaksanakan pembedahan dengan anestesi resiko tinggi, oleh karena ini adalah operasi darurat maka mohon dijelaskan kepada keluarga resiko yang bisa terjadi "darut"/ sebelum operasi atau "post"/ usai operasi. Bahwa penyebab udara masuk dari setiap pembuluh darah balik yang terbuka yaitu dari infus atau dari suntikan obat tetapi dalam kepustakaan dikatakan udara yang masuk dari pembuluh darah balik ini hanya bisa menyebabkan kecelakaan penting yang kalau dia di atas $25 \mathrm{mg}$ dan kalau di bawah tidak akan menyebabkan apa-apa, kemudian dalam kenyataan pemberian obat dari infus tidak pernah masuk udara karena dari suntik disposible untuk masuk udara, selanjutnya dari kepustakaan yang saksi baca dan saksi dapat dalam pendidikan saksi yaitu kemungkinan yang bisa juga adalah terutama dalam operasi persalinan bahkan di dalam aturan dikatakan bahwa udara bisa masuk sering terjadi pada operasi bedah saraf dengan posisi pasien setengah duduk bisa terjadi pada saat dia terkemuka itu udara bisa masuk, pada bagian kebidanan yang bisa sering terjadi bukan saja pada SECTIO CESARIA tetapi juga pada kuretase bahkan dalam laporan kasus yaitu untuk hubungan intim dimana suami memakai oral itu bisa terjadi masuk udara,Kasus ini memang jarang tetapi bisa saja terjadi, jadi pada waktu bayi lahir plasenta terangkat pembuluh darah itu terbuka yaitu pembuluh darah arteri/ pembuluh darah yang pergi yang warna merah dan pembuluh darah balik/ arteri yang warna hitam, jadi kemungkinan udara yang masuk berdasarkan hasil visum bisa saja terjadi dari beberapa hal tadi, selanjutnya tugas anestesi dalam hal ini telah selesai karena pasien/ korban sudah membuka mata dan bernapasspontan kecuali jika saat 
pasien sebelum dirapihkan semua kemudian meninggal maka masih merupakan tugas dan tanggung jawab dari anestesi dan kebidanan."

Dalam pembahasan terkait resiko medis, masuknya udara tersebut merupakan salah satu kategori resiko medis karena terjadinya emboli udara tersebut tidak dapat diduga oleh dokter yang melakukan pelayanan medis. Dapat diketahui matinya korban bukan karena kesalahan atau kelalaian dokter dalam memberikan pelayanan medis tetapi karena resiko dari tindakan medis tersebut muncul sehingga dokter tidak dapat dimintai pertanggungjawaban atas matinya pasien yang dalam penanganannya.

Dalam putusan peninjauan kembali (PK) yang hanya boleh dilakukan sekali, majelis hakim memutuskan bahwa dokter Ayu beserta tim dokter dibebaskan. Putusan peninjauan kembali tersebut menguatkan putusan Pengadilan Negeri Manado Nomor 90/Pid.B/2011/PN.MDO bahwa Dokter Ayu beserta tim dokter tidak bersalah. Putusan peninjauan kembali juga mempertimbangkan putusan Majelis Kehormatan Disiplin Kedokteran Indonesia (MKDKI) yang menyatakan bahwa dokter Ayu beserta tim dokter tidak menyalahi Standar Operasional Prosedur (SOP).

\section{PERTANGGUNGJAWABAN DALAM HUKUM PIDANA}

Perbuatan pidana hanya menunjuk kepada dilarang dan diancamnya perbuatan dengan suatu pidana. Apakah orang yang melakukan perbuatan kemudian juga dijatuhi pidana, sebagaimana telah diancamkan, ini tergantung dari soal apakah dalam melakukan perbuatan ini dia mempunyai kesalahan. Sebab azas dalam peranggungjawaban dalam hukum pidana ialah : Tidak dipidana jika tidak ada kesalahan (Geen straf zonder schuld; Actus non facit reum nisi mens sir rea). Dalam pertanggungjawaban dokter terhadap resiko medis, unsur kesalahan yang dipakai adalah kelalaian atau kealpaan atau di dalam istilah hukum kesehatan disebut dengan Negligence.

Langemeyer "Kealpaan adalah suatu struktur yang sangat gecompliceerd. Dia mengandung dalam satu pihak kekeliruan dalam perbuatan lahir dan menunjuk kepada adanya keadaan batin yang tertentu, dan di lain pihak keadaan batinnya itu sendiri". Van Hammel mengatakan bahwa kealpaan itu mengandung dua syarat yaitu :

1. tidak mengadakan penduga - duga sebagaimana diharuskan oleh hukum. 
2. tidak mengadakan penghati - hati sebagaimana diharuskan oleh hukum.

Dalam Bab sebelumnya telah diketahui perbedaan antara resiko medis dengan kelalaian medis. Bahwa dalam menentukan unsur kesalahan berupa kelalaian, dalam hukum kesehatan perlu patokan yaitu berdasarkan standar operasional prosedur, standar profesi, dan pendapat kalangan profesi dokter.

\section{PENUTUP}

Berdasarkan hasil analisis yang dilakukan terhadap data-data yang diperoleh guna memperoleh jawaban atas permasalahan yang diteliti, maka pada bab ini penulis akan melakukan analisa kesimpulan dan pemberian saran atas masalah yang ditelitinya.

a. Patokan untuk menentukan sebuah hasil pengobatan yang gagal dikategorikan resiko medis atau kelalaian medis adalah dari standar operasional prosedur, standar profesi dan pendapat kalangan profesi dokter sendiri. Ketiga patokan ini juga dapat dilihat dari putusan pengadilan tentang kasus yang menimpa dokter Ayu dan menjadi pertimbangan majelis hakim untuk membebaskan dokter Ayu beserta tim dokternya.

b. Resiko medis merupakan hasil yang tidak maksimal dari sebuah tindakan medis. Resiko medis sendiri terbagi menjadi 2(dua) yaitu resiko medis yang dapat dimintakan pertanggungjawaban kepada dokter dan resiko medis yang tidak dapat dimintakan pertanggungjawaban kepada dokter. Resiko medis yang tidak dapat dimintakan pertanggungjawaban kepada dokter merupakan resiko medis yang muncul karena sifat alami dan besarnya resiko yang timbul dari tindakan medis tanpa adanyafaktor kesalahan ataupun kelalaian yang dilakukan oleh pihak dokter. Sedangkan resiko medis yang dapat dimintakan pertanggungjawaban kepada dokter merupakan resiko medis yang muncul karena tindakan medis yang dilakukan oleh dokter mempunyai resiko besar dan resiko tersebut muncul dikarenakan adanya unsur lalai yang dilakukan oleh dokter.

\section{DAFTAR PUSTAKA}

Hermien Hadiati Koeswadji (1992:17) dikutip dari Bahder Johan Nasution,Hukum 
Kesehatan Pertanggungjawaban Dokter,Rineka Cipta,Jakarta,2013,hal.1

Undang - Undang Republik Indonesia Nomor 36 Tahun 2009 Tentang Kesehatan,Bab

I,Pasal 1 angka 1

Kitab Undang - Undang Hukum Perdata

Internet, www.kamusbesarbahasaindonesia.org/kode\%20etik/mirip

Bahder Johan Nasution,Hukum Kesehatan Pertanggungjawaban Dokter,Rineka Cipta,Jakarta,2013,h.9

Anny Isfandyarie (Selanjutnya ditulis “Anny Isfandyarie (2)” ), Malpraktek dan Resiko Medik dalam Kajian Hukum Pidana,Prestasi Pustaka,Jakarta,2005,h.38

Moeljatno,Asas - Asas Hukum Pidana,Rineka Cipta,Jakarta,1993,h.200

M Yusuf Hanafiah dan Amri Amir, Etika Kedokteran dan Hukum Kesehatan, EGC, Jakarta,1999, h.87

Guwandi,Pengantar Ilmu Hukum Medik \& Bio-etika,Balai Penerbit Fakultas Kedokteran Universitas Indonesia, Jakarta,2009,h.1 